\title{
Large-cell neuroendocrine carcinoma that presented with bone marrow replacement
}

\author{
Hiroyuki Nagano $^{1 *}$, Yuya Nagai ${ }^{2}$, Futoshi Iioka ${ }^{2}$, Gen Honjo $^{3}$, Masahiko Hayashida ${ }^{4}$, Hiroyasu \\ Ishimaru $^{1}$, Kazuhiro Hatta ${ }^{1}$ \\ ${ }^{1}$ Department of General Internal Medicine, Tenri Hospital; ${ }^{2}$ Department of Hematology, Tenri Hospital; ${ }^{3}$ Department of \\ Diagnostic Pathology, Tenri Hospital; ${ }^{4}$ Tenri Institute of Medical Research, *Present address: Department of Emergency \\ and General Internal Medicine, Rakuwakai Marutamachi Hospital
}

Received 2016/9/1; accepted 2017/5/24; released online 2017/7/1

An 84-year-old male smoker, who underwent left upper lobectomy for a lung adenocarcinoma six years earlier, was admitted to our institution due to loss of appetite and exertional dyspnea. Computed tomography scanning demonstrated a tumor shadow in the upper lobe of the right lung, mediastinal lymphadenopathy, and tumor shadows in the liver. His blood test revealed anemia (hemoglobin, $9.9 \mathrm{~g} / \mathrm{dL}$ ), thrombocytopenia (platelet count, $32 \times 10^{3} / \mu \mathrm{L}$ ), and increased serum levels of lactate dehydrogenase (2,391 IU/L) and soluble interleukin-2 receptor $(6,954 \mathrm{U} / \mathrm{mL})$. Examination of the bone marrow smear showed large neoplastic cells, comprising $70 \%$ of nucleated cells, and the cells lacked expression of lymphoid and myeloid antigens on flow cytometry analysis. A bone marrow biopsy demonstrated that the marrow space was replaced by the proliferation of large neoplastic cells, and some areas exhibited an organoid nesting pattern. Immunohistochemistry revealing that neoplastic cells were positive for synaptophysin and chromogranin established the diagnosis of large-cell neuroendocrine carcinoma (LCNEC). This replacement of bone marrow with carcinoma cells is a rare presentation of LCNEC and abnormalities in laboratory test results resembled those in hematolymphoid tumors.

Keywords: large-cell neuroendocrine carcinoma, bone marrow replacement, anemia, thrombocytopenia, high level of soluble interleukin-2 receptor

\section{INTRODUCTION}

Neuroendocrine carcinomas (NECs) are classified as large-cell neuroendocrine carcinomas (LCNECs) and small cell carcinomas (SCCs). ${ }^{1}$ LCNECs have been reported in several organs such as the lungs, breasts, urinary bladder, colon, gallbladder, ovaries, and uterine cervix. ${ }^{2}$ The metastatic organ sites of LCNECs include

*Correspondence to: Hiroyuki Nagano, MD

Department of Emergency and General Internal Medicine, Rakuwakai Marutamachi Hospital, 9-7 Jurakumawarimatsushita-cho, Nakagyo,

Kyoto 604-8401, Japan. e-mail: nagano0408@gmail.com the lymph nodes, liver, bone, lung, and brain. ${ }^{2,3}$ To the best our knowledge, bone marrow involvement with LCNECs has rarely been described. Here, we report a case of LCNEC, in which carcinoma cells replaced the bone marrow. Laboratory test results revealed anemia, thrombocytopenia, and high levels of lactate dehydrogenase (LDH) and soluble interleukin-2 receptor (sIL-2R), which resembled those in hematolymphoid tumors.

\section{CASE REPORT}

An 84-year-old male smoker was admitted to our in- 
stitution because of loss of appetite and exertional dyspnea for 1 month. Six years earlier, he had undergone lobectomy of the left upper lobe for lung adenocarcinoma. One year ago, he developed another lung tumor shadow in the right upper lobe, which was treated by stereotactic body radiotherapy with a total dose of 50 Gy without a pathological diagnosis. For 60 years, he had smoked 20 cigarettes a day, and he had a history of angina pectoris.

On examination, his body temperature was $37.1^{\circ} \mathrm{C}$, respiratory rate was 20 breaths/min, and oxygen saturation was $93 \%$. In addition, his blood pressure and pulse rate were normal. There was no purpura or surface lymphadenopathy. Computed tomography (CT) scan with administration of a contrast material displayed a tumor shadow measuring $54 \times 44 \times 40 \mathrm{~mm}$ in the upper lobe of the right lung, mediastinal lymphadenopathy that compressed the superior vena cava, and multiple tumors in the liver (Figure 1).

The patient's hemoglobin level was $9.9 \mathrm{~g} / \mathrm{dL}$ (range,
$13.1-17.0 \mathrm{~g} / \mathrm{dL})$, reticulocyte production index was 0.6 (0.6-1.3), white blood cell count was $8.58 \times 10^{3} / \mu \mathrm{L}$ $\left(3.50-8.50 \times 10^{3} / \mu \mathrm{L}\right)$, and platelet count was $32 \times 10^{3} /$ $\mu \mathrm{L}\left(15.0-35.0 \times 10^{4} / \mu \mathrm{L}\right)$. His white blood cell differential count was $35 \%$ lymphocytes, $18 \%$ monocytes, $44 \%$ segmented neutrophils, and 3\% band neutrophils. There was no red blood cell fragmentation. Blood chemistry test levels were as follows: LDH, 2,391 IU/L (100-225 IU/L); aspartate aminotransferase, 98 IU/L (11-32 IU/ L); alanine aminotransferase, 12 IU/L (3-30 IU/L); total bilirubin, $1.4 \mathrm{mg} / \mathrm{dL}(0.2-1.0 \mathrm{mg} / \mathrm{dL})$; and alkaline phosphatase, 353 IU/L (100-335 IU/L). The calcium level in the blood was $11.3 \mathrm{mg} / \mathrm{dL}(8.4-10.0 \mathrm{mg} / \mathrm{dL})$. In addition, the prothrombin time was $14.4 \mathrm{sec}$ (10.5-13.3 $\mathrm{sec})$, activated partial thromboplastin time was $28.5 \mathrm{sec}$ (23.0-35.0 sec), and D-dimer concentration was $2.1 \mu \mathrm{g} /$ $\mathrm{mL}(<1.0 \mu \mathrm{g} / \mathrm{mL})$. The serum ferritin concentration was $2,700 \mathrm{ng} / \mathrm{mL}(10-260 \mathrm{ng} / \mathrm{mL})$ and sIL-2R concentration was $6,954 \mathrm{U} / \mathrm{mL}(145-519 \mathrm{U} / \mathrm{mL})$.
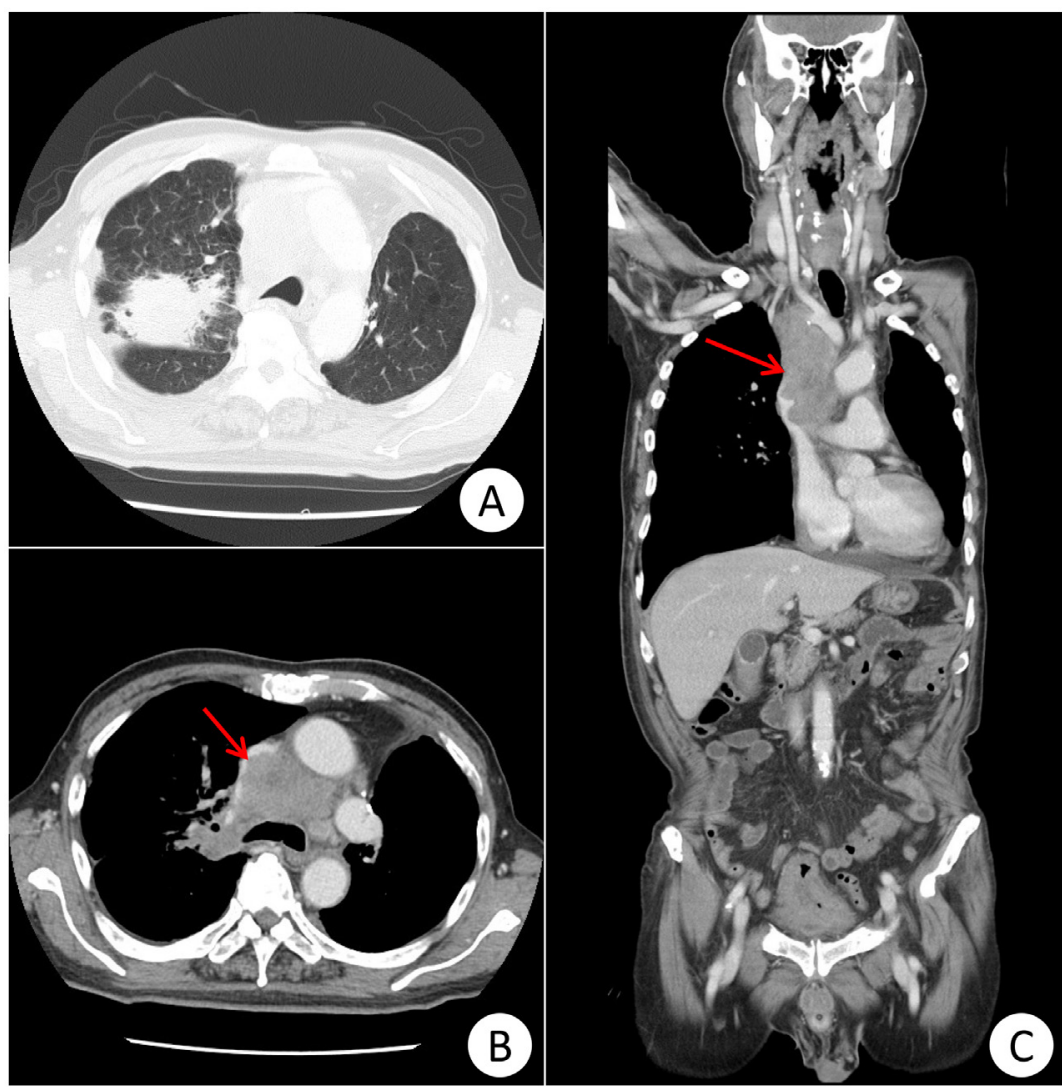

Figure 1. Computed tomography image on admission. Axial sections of the thorax showed a tumor in the upper lobe of the right lung ( $A$, lung window), and mediastinal and hilar adenopathy (arrow) ( $B$, mediastinal window). $C, A$ coronal reformatted image from a whole-body scanning image shows a mediastinal mass (arrow) causing compression of the superior vena cava. 
Owing to suspicion of hematolymphoid malignancy involving bone marrow from these laboratory results, we performed a bone marrow test. The examination of the bone marrow smear revealed large neoplastic cells with nuclei measuring $21 \times 15 \mu \mathrm{m}$, folded and irregular nuclear contours, basophilic cytoplasm, and cytoplasmic vacuoles (Figure 2). Some cells formed clusters, but overall, the cells had fine chromatin, inconspicuous nucleoli, and basophilic cytoplasm-containing vacuoles. The biopsy specimen demonstrated that the marrow space was replaced by the proliferation of large neoplastic cells and that some areas had an organoid nesting pattern (Figure 2). Moreover, the cells had three- to four-fold larger nuclei than normal lymphocytes. There were more than 10 mitotic figures per $10 \mathrm{HPF}$.
The flow cytometry analysis of neoplastic cells showed that the cells expressed CD56, but lacked the specific lymphoid and myeloid cell antigens. The DNA index of 1.74 was proportional with normal diploid cells (Figure 3). Immunohistochemistry of the biopsy specimen confirmed the absence of the T-cell antigen CD3 and the B-cell antigen CD20. The specimen was subsequently stained with antibodies against non-hematological tumors, and was positive for AE1/AE3, CAM5.2, synaptophysin, chromogranin, and cytokeratin 20 (CK20) in the cytoplasm, but negative for cytokeratin 7, thyroid transcription factor-1 (TTF-1), prostate-specific antigen, napsin $\mathrm{A}$, and anaplastic lymphoma kinase (Figure 4). The test for detecting an epidermal growth factor receptor mutation was negative.

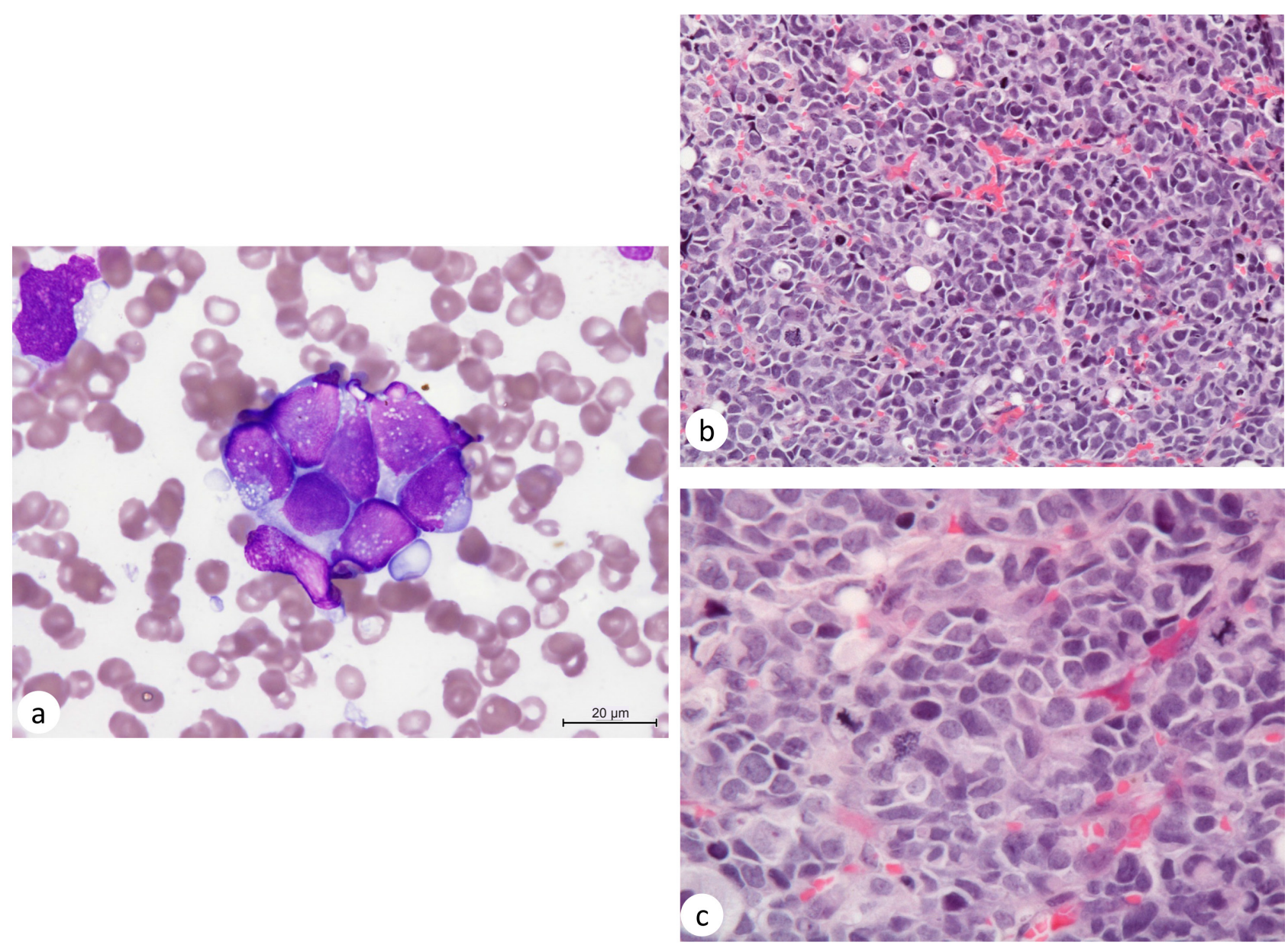

Figure 2. Appearance of the bone marrow. a, Bone marrow aspirate smear (Wright's staining; original magnification, $\times 100$ objective lens). $b$ and $c$, Bone marrow biopsy. Hematoxylin-eosin staining (original magnification, $\times 20$ and $\times 40$ objective lenses). A large neoplastic cell showed an organoid nesting pattern in $b$. 

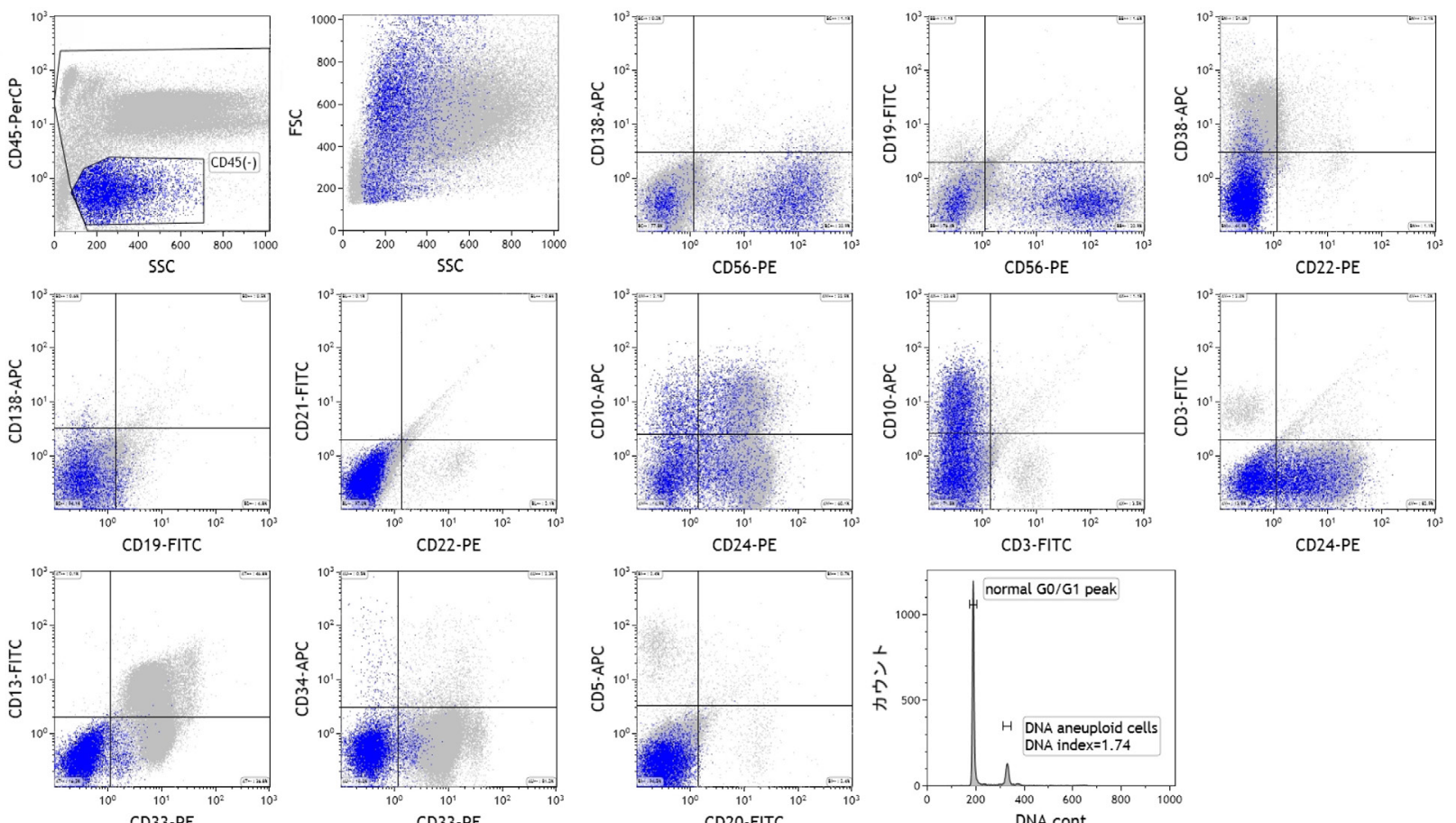

Figure 3. Multicolor flow cytometry of neoplastic cells using monoclonal antibodies for indicated antigens. CD45-negative neoplastic cells indicated with blue exhibit expression of CD56 and negative to weak expression of CD10, while the other lymphoid and myeloid antigens are negative.
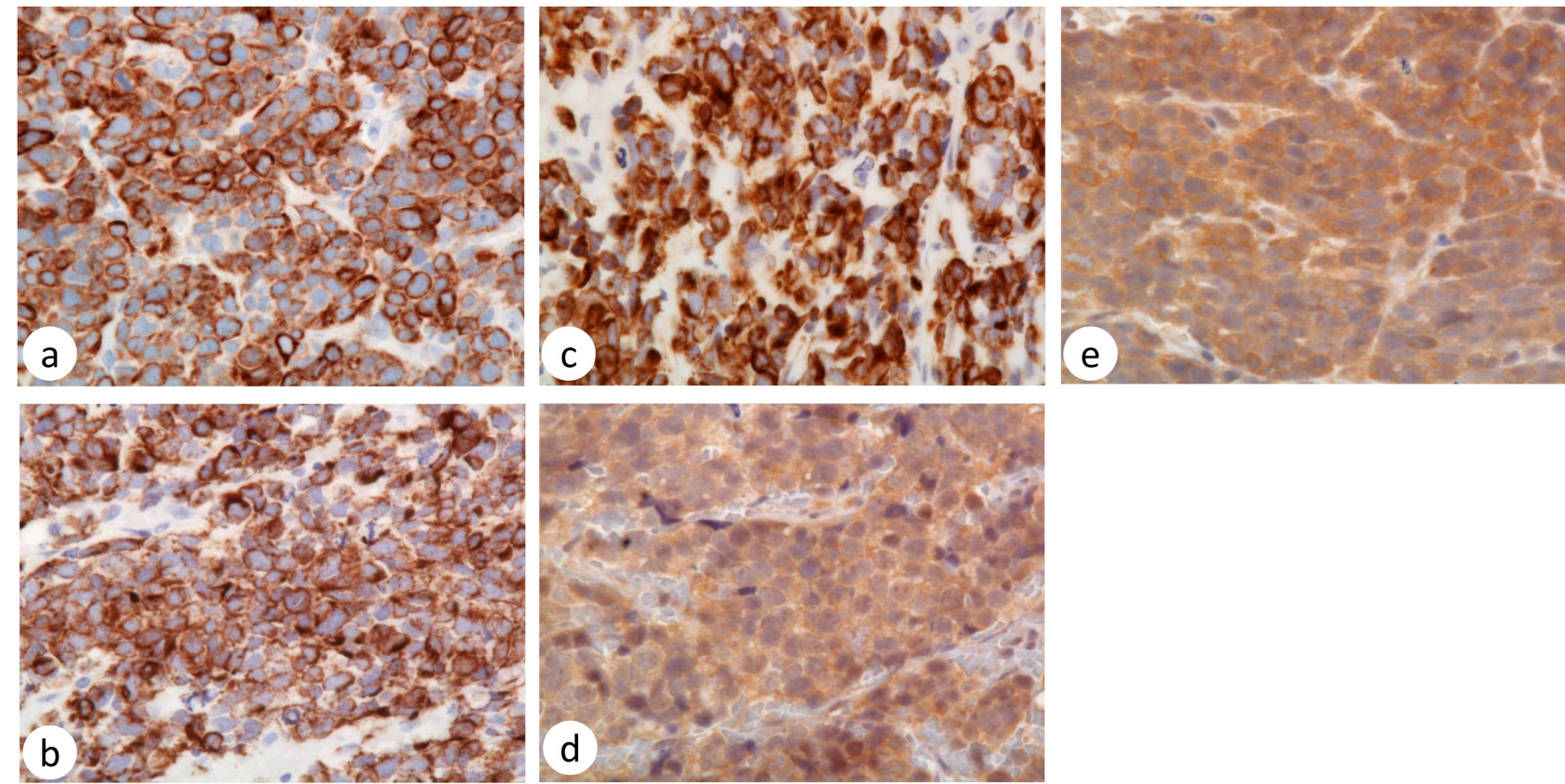

Figure 4. Immunohistochemistry. a, AE1/AE3; $b$, CAM5.2; c, cytokeratin 20; $d$, chromogranin A; and e, synaptophysin. Original magnification, $\times 40$ objective lens. 
Collectively, we diagnosed the patient as having LC$\mathrm{NEC}$, the primary site of which was possibly the right upper lobe of the lung based on the findings of the chest CT (as shown in Figure 1). The concentration of CYFRA was $21.1 \mathrm{ng} / \mathrm{mL}$ (range, $<3.5 \mathrm{ng} / \mathrm{mL}$ ) and that of NSE was 945 ng/mL (range, $<16.3$ ng/mL). The concentrations of CEA and Pro-GRP were normal. However, the patient succumbed to the disease on the $22^{\text {nd }}$ day, and autopsy was not performed.

\section{DISCUSSION}

In this report, we described a rare presentation of LCNEC with prominent bone marrow involvement. Reportedly, both microangiopathic hemolytic anemia and leukoerythroblastic anemia are observed in approximately $70 \%$ of patients with solid tumors and with bone marrow metastases. ${ }^{4,5}$ In contrast, hematological manifestations in the present case, i.e., anemia lacking reticulocytosis and thrombocytopenia without coagulation test abnormalities, suggested the suppression of hematopoiesis resulting from extensive bone marrow infiltration. Furthermore, the high levels of LDH and sIL-2R prompted us to suspect the presence of a hematolymphoid tumor. However, the bone marrow examination revealed abundant large neoplastic cells expressing neuroendocrine markers, which led to the diagnosis of LCNEC. Bone marrow involvement in LCNEC has rarely been described. In one case, LCNEC from an unknown primary site demonstrated extensive bone marrow infiltration with anemia, thrombocytopenia, and leukoerythroblastosis; in another case, LCNEC of the epiglottis presented with liver and bone marrow involvement, and very high levels of LDH. ${ }^{6,7}$ Both cases, similar to our case, presented with abnormal laboratory data mimicking a hematological malignancy. Elevated levels of sIL-2R are reported in not only hematolymphoid malignancies but also in advanced stages of lung cancer and are likely to be the product of activated normal lymphoid cells in response to the growth of cancer cells. ${ }^{8,9}$ Moreover, the elevated levels of ferritin have also been reported in malignancies. ${ }^{10}$ Notably, serum ferritin is an acutephase reactant, and its level is non-specifically elevated in several inflammatory states, including malignancy, infection, and autoimmune disease.

Although LCNEC is well characterized in the lungs, it is not sufficiently defined in other organs. According to the WHO classification of lung tumors, LCNECs display the following histopathological features: 1) neuroendocrine morphology (organoid nesting pattern, palisades pattern, and solid nests with rosette-like structures), 2) high mitotic rate $\left(>10\right.$ per $\left.\left.2 \mathrm{~mm}^{2}\right), 3\right)$ tumor necrosis (often large zones), 4) cytological features of non-SCCs (large cell size with moderate to abundant cytoplasm and numerous nucleoli), and 5) positive immunostaining for neuroendocrine markers (chromogranin, synaptophysin, and neural cell adhesion molecule). ${ }^{11}$

Distinguishing LCNECs from SCCs can be difficult in some cases because no single feature can be used to clearly segregate SCCs and LCNECs; hence, a combination of features must be taken into account. Moreover, its evaluation must be subjective to some extent. In one study, ${ }^{12}$ there was a unanimous diagnostic agreement on $70 \%$ of SCCs and $40 \%$ of LCNECs in surgically resected neuroendocrine tumors of the lung that were independently reviewed by five pulmonary pathologists. Tumor cells in our patient did not have numerous nucleoli. However, the distinction between SCCs and LCNECs has little clinical value because of the similar therapeutic protocol. ${ }^{13}$ Some groups have suggested that SCCs and LCNECs in the lung should be combined into a single group in daily practice as a high-grade NEC. ${ }^{14}$

The specimen from our patient was positive for CK20 and negative for TTF-1. CK20, which is a 46-kDa basic protein, is confined to intestinal epithelial cells, urothelial cells, and Merkel cells. ${ }^{15}$ TTF-1 is a nuclear transcription factor that regulates cell growth and differentiation in thyroid, lung, and selected brain tissues. ${ }^{16}$ These immunohistochemical markers are useful for identifying the primary site of origin. Regarding metastatic carcinomas in cervical lymph nodes, TTF-1 has a specificity 
of 0.95 and a sensitivity of 0.69 for detecting metastatic lung carcinomas, whereas CK20 has a specificity of 1.00 and sensitivity of 0.69 for detecting metastatic gastrointestinal carcinomas. ${ }^{17}$ For LCNECs, CK20-positive cases are not restricted to gastrointestinal carcinomas and have a different primary site, including the ovaries, skin, urinary bladder, and breast. ${ }^{15}$ In our case, the primary site was considered to be the lung; this was where the main lesion was located in the CT scan image.

In conclusion, we diagnosed a rare case of LCNEC that demonstrated prominent bone marrow involvement, and the abnormalities in the laboratory tests resembled those in hematolymphoid tumors. A careful histopathological examination of the bone marrow biopsy specimen using appropriate antibodies established the diagnosis of the disease.

\section{REFERENCES}

1. Bosman FT, Carneiro F, Hruban RH, et al., eds. World Health Organization Classification of Tumours of the Digestive System. 4th ed. Lyon: IARC; 2010.

2. Faggiano A, Sabourin JC, Ducreux M, et al. Pulmonary and extrapulmonary poorly differentiated large cell neuroendocrine carcinomas: diagnostic and prognostic features. Cancer 2007;110:265-274.

3. Derks JL, Hendriks LE, Buikhuisen WA, et al. Clinical features of large cell neuroendocrine carcinoma: A population-based overview. Eur Respir J 2016;47:615-624.

4. Ohno H. Metastatic cancer of the bone marrow. Tenri Medical Bulletin 2013;16:136-137.

5. Lai GM, Lin J-T, Chang C-S. Metastatic bone marrow tumors manifested by hematologic disorders: Study of thirty-four cases and review of literature. J Anal Oncol 2014;3:185-190.

6. Patel KJ, Chandana SR, Wiese DA, et al. Unusual presentation of large-cell poorly differentiated neuroendocrine car- cinoma of the epiglottis. J Clin Oncol 2010;28:e461-463.

7. Salathiel I, Wang C. Bone marrow infiltrate by a poorly differentiated neuroendocrine carcinoma. Pathol Res Pract 2003;199:483-486; discussion 487-488.

8. Naumnik W, Chyczewska E. The clinical significance of serum soluble interleukin 2 receptor (sIL-2R) concentration in lung cancer. Folia Histochem Cytobiol 2001;39 Suppl 2:185-186.

9. Bien E, Balcerska A. Serum soluble interleukin 2 receptor alpha in human cancer of adults and children: A review. Biomarkers 2008;13:1-26.

10. Moore C Jr, Ormseth M, Fuchs H. Causes and significance of markedly elevated serum ferritin levels in an academic medical center. J Clin Rheumatol 2013;19:324-328.

11. Brambilla E, Pugatch B, Geisinger K, et al. Large cell carcinoma. In: Travis WD, Brambilla E, Müller-Hermelink HK, Harris CC, eds. Word Health Organization Classification of Tumours. Pathology and Genetics of Tumours of the Lung, Pleura, Thymus and Heart. Lyon: IARC; 2004:45-50.

12. Travis WD, Gal AA, Colby TV, et al. Reproducibility of neuroendocrine lung tumor classification. Hum Pathol 1998;29:272-279.

13. Kalemkerian GP, Loo BW, Akerley W. NCCN (National Comprehensive Cancer Network). Small Cell Lung Cancer, version 2.2017. (https://www.tri-kobe.org/nccn/guideline/lung/english/small.pdf). Accessed on April 24, 2017.

14. Marchevsky AM, Gal AA, Shah S, et al. Morphometry confirms the presence of considerable nuclear size overlap between "small cells" and "large cells" in high-grade pulmonary neuroendocrine neoplasms. Am J Clin Pathol 2001;116:466-472.

15. Shin MK, Choi CM, Oh YJ, et al. CK20 positive largecell neuroendocrine carcinoma presenting with skin metastases. Ann Dermatol 2011;23 Suppl 1:S20-24.

16. Ordóñez NG. Thyroid transcription factor-1 is a marker of lung and thyroid carcinomas. Adv Anat Pathol 2000;7:123-127.

17. Roh MS, Hong SH. Utility of thyroid transcription factor- 1 and cytokeratin 20 in identifying the origin of metastatic carcinomas of cervical lymph nodes. J Korean Med Sci 2002;17:512-517. 


\section{骨髄浸潤を認めた肺大細胞神経内分泌癌の 1 例}

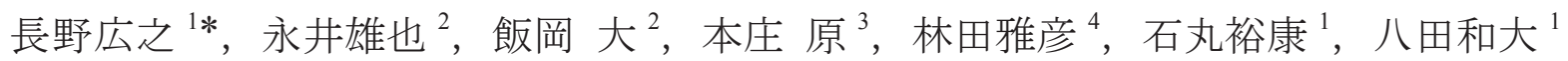

${ }^{1}$ 天理よろづ相談所病院 総合内科

2 天理よろづ相談所病院 血液内科

$3^{3}$ 天理よろづ相談所病院 病理診断部

4 天理よろづ相談所 医学研究所

*現所属 : 洛和会丸太町病院 救急総合診療科

6 年前に肺腺癌で左上葉切除を受けた 84 歳男性. 食欲低下，労作時呼吸苦で当科に入院した. CTで右肺上葉 に腫瘤性陰影と縦隔リンパ節腫脹，肝多発腫瘤を認めた。採血では貧血 (ヘモグロビン $9.9 \mathrm{~g} / \mathrm{dL}$ )，血小板減少 ( 血小板数 $\left.32 \times 10^{3} / \mu \mathrm{L}\right) ， \mathrm{LDH}$ 高値 $(2,391 \mathrm{IU} / \mathrm{L}) ， \mathrm{sIL}-2 \mathrm{R}$ 高値 $(6,954 \mathrm{U} / \mathrm{mL})$ が認められた. 骨䯣穿刺液の塗抹標本 では大型の腫瘍細胞を認め，これらは全有核細胞の $70 \%$ を占めた. フローサイトメトリー解析では腫瘍細胞に おけるリンパ系，骨髄系の表面抗原の発現を認めなかった．骨髄生検では骨梁間を埋めるような密な腫瘍細胞の 増生が認められ，一部は “organoid nesting appearance” を示していた. 免疫染色で腫瘍細胞は synaptophysin， chromogranin が陽性であり，大細胞神経内分泌癌と診断した。本症例では腫瘍細胞が骨髄浸潤し，血液リンパ系 腫瘍に似た検査異常を示すという大細胞神経内分泌癌として稀な経過を示した.

キーワード：大細胞神経内分泌癌，骨䯣浸潤，貧血，血小板減少， SIL-2R 高值 